farming there has been an increase from 12,200 persons in 1921 to 27,700 in 1931. The manufacture of electrical apparatus, chemicals, paints and oils; hosiery; food; printing and bookbinding; road transport; and a number of other industries have expanded considerably in both census periods since 1911. An interesting fact recorded in the latest census is a great increase in the number of male commercial travellers, from 81,347 in 1921 to 120,212 in 1931 .

\section{Economic Study of Japan's Population Problems}

"Conflict and Co-operation, Economic and Political, in the Pacific" formed the theme of the Cawthron Lecture, 1934, delivered by Mr. Frank Milner, at Nelson, New Zealand (Nelson, N.Z. : Cawthron Institute, 1934). There are, he said, ominous explosive potentialities in Japan's growing population pressure with its increase of more than one million per annum. Her population density is now 437 persons to the square mile, and though this is exceeded by Java, Belgium, England and Holland, the situation is complicated by the fact that only 16 per cent of the land is arable. With 2,774 persons living on each square mile of such land-not a foot of land being wasted-Japan has reached the point of complete saturation. Half the farms are less than $1 \frac{1}{2}$ acres in extent and three-quarters less than $2 \frac{1}{2}$ acres. The Japanese are not an emigrating people, and there are only about 635,000 living abroad. The only feasible solution of the basic population problem of Japan is the development of manufacture and trade, though inadequate resources of coal, iron ore, petroleum and other raw materials handicap her industrial expansion. Moreover, Manchuria, according to scientific experts, cannot provide coal or iron ore of the type needed for Japanese blast-furnaces. The shift from an agricultural to an industrial economy is far from complete, and at present less than 10 per cent of the population work in factories employing more than five persons. Japan to-day is the real problem of the Pacific, and her isolation is breeding an ugly mood in her militarists. The solution may involve regional allocation of raw materials and markets to Japan involving heavy sacrifices, but such co-operative effort must be made if a cataclysm is to be avoided.

\section{François Emmanuel Fodéré}

THE centenary of the death of Francois Emmanuel Fodéré, who was born on January 8,1764 , is to be celebrated on April 12 at Strasbourg, where he was professor of medical jurisprudence from 1814 until 1834. His "Traité de médecine légale et d'hygiène publique ou de police sanitaire", of which the first edition was published in 1798 and the second in 1813, was the standard work in medical jurisprudence in France during the early part of the last century. In 1819 he was appointed lecturer in the history of epidemic diseases and hygiene at Strasbourg, his lectures being afterwards published in four volumes in 1822-24. His other works included "Traité du goître et du crétinisme, précédé d'un discours sur l'influence de l'air humide sur l'entendement humain" (1790), "Essai historique et moral sur la pauvreté des nations, la population, la mendicité, les hôpitaux et les enfants trouvés" (1825), "Recherches sur la nature, les causes et le traitement du Choléramorbus" (1831) and "Essai sur les diverses espèces de folie" (1832).

\section{Moses Maimonides}

The January issue of Medical Life is a Maimonides number containing an account by Prof. Louis Gershenfeld, of the Philadelphia College of Pharmacy and Science, of the Hispano-Jewish physician, astronomer and theologian, Moses Maimonides or Abu Amran Musa Ben Maimon, on the occasion of the octocentenary of his birth. Born at Cordova in Spain on March 30, 1135, he studied under Averrhocs, and in 1160 left Spain for Fez, finally settling in 1165 at Cairo, where he died on December 13, 1204. His best-known medical work is a collection of 1,500 aphorisms from Galen's writings with forty-two critical comments. His other chief medical works are a treatise on diet and personal hygiene written at the request of Saladin's eldest son, who suffered from melancholia, and a book on poisons and antidotes. In a work on astronomy, he recognised the limitations of astrology, and declared that all works on the subject were the products of fools. He differentiated between astrology and astronomy, maintaining that in the latter only was to be found true and necessary knowledge. His most famous work, however, was the "Guide for the Perplexed", which was not intended for popular consumption, but claimed to be written by a philosopher to the philosophically minded, his purpose being to reconcile Aristotelian philosophy with Jewish theology and the doctrines of Judaism.

\section{Water with Heavy Oxygen}

There has recently been erected in the Chemistry Department of the University of Manchester an apparatus of the type first described by Hertz (Z. Phys., 79, 108; 1932) and afterwards modified by Harmsen ( $Z$. Phys., 82, 589; 1933) for the separation of gaseous isotopes by diffusion. The immediate object is to prepare oxygen containing an excess over the normal of the $\mathrm{O}^{18}$ isotope. For this purpose it is convenient to diffuse water vapour rather than oxygen itself. The abundance of $\mathrm{H}_{2} \mathrm{O}^{18}$ is approximately $\mathrm{l}: 500$ and the ratio of the vapour densities of the 'heavy' and 'normal' water is $10: 9$. The apparatus was designed to vield water containing about one per cent of $\mathrm{H}_{2} \mathrm{O}^{18}$. The process of separation is very much slower with water vapour than with permanent gases owing to the adsorption of the vapour on the walls of the porous tubes used for the diffusion. This adsorption is large even at $100^{\circ} \mathrm{C}$. A trial run just completed has yielded about $20 \mathrm{mgm}$. of water the density of which is greater than normal by about 25 parts per million, which is scarcely if at all outside the experimental error of the density measurement. The apparacus is now being modified somewhat to allow of faster working, and it is hoped that it will yield about $20 \mathrm{mgm}$. a day of water 
containing 0.5 to 1 per cent of $\mathrm{H}_{2} \mathrm{O}^{18}$. The water so obtained (or the oxygen prepared from it) will be used as an 'isotopic indicator' in reactions involving oxygen. A specimen of such water prepared by Hertz has already been used to investigate the mechanism of saponification of esters (Polanyi and Szabo: Trans. Faraday Soc., 30, 508 ; 1934.)

\section{The Naturalist in the Laboratory}

Sir Frederick Gowland Hopkins delivered the Bacot Memorial Lecture entitled "The Naturalist in the Laboratory" before the London Natural History Society on April 2. Sir Frederick pointed out that early biology was limited to study of the physiology and morphology of plants and animals (chiefly vertebrates), the causes which affected them being largely conjectural ; the chemist provided means of elucidating these problems. Observation of the bombardier beetle and its explosive excretion first attracted Sir Frederick's notice to these matters fifty seven years ago, and despite this first experiment proving fruitless, it was this which led to his taking up biochemistry. The work of the biochemist in comparing the action of catalysis with enzymes has established the processes at work which enable both plant and animal to digest and transform food materials into substances suitable for oxidation to enable life to continue. But it does not stop there, for it has shown the relationship between species by the parallel processes carried on in similar species, and that each species may have its own process. A further stage has been to show the necessity for certain substances to allow the full utilisation of food supplies. Known as vitamins, they provide the means for the body to obtain enough fuel to supply full growth and reduce vulnerability to disease. Although systematic, taxonomic, morphological and physiological research must continue, and the biochemist can still open new avenues for exploration, there is every scope for wide co-operation between all branches of natural history from an ecological point of view. Finally, although exact chemical reactions in plant and animal can be ascertained and reproduced experimentally, and although living tissues can be made to function under artificial conditions, the origin and nature of life is a matter which scientific research has yet to explain.

\section{A New Wind Tunnel}

THE new 24-ft. wind tunnel at the Royal Aircraft Establishment, Farnborough, opened by the Secretary of State for Air on April 5, is the largest in Great Britain. It can contain a complete aeroplane, all of the machine except the outer portions of the wings being in the air stream and under observation. Air speeds equivalent to 115 miles per hour are obtained. The principal immediate use of this type of tunnel is the investigation of 'interference' between various bodies in juxtaposition, such as airscrews and engine cowlings, which cannot be studied precisely upon small-scale models. Such problems cannot be examined as fully as is necessary in actual flight owing to the uncertainty of the steadiness of the air at the moment of taking an observation, and moreover, such experimental flying with new and untried design ideas involves considerable risk, and often delay, in bad weather. This tunnel is not the largest in the world, there being a $60 \mathrm{ft} . \times 30 \mathrm{ft}$. one at Langley Field, United States, and a $50 \mathrm{ft}$. span one in France (see Nature, Feb. 16, 1935, p. 252). It is interesting to note that one of the first machines to be investigated in this channel will be a new one that has exceeded its anticipated performance in certain respects by so much as to shake confidence in the accepted methods of estimating the total air resistance of combinations of differently shaped bodies.

\section{Shortt Clock at the Science Museum}

A SHoRTT free pendulum clock has recently been installed at the Science Museum, South Kensington, and is now at work controlling the main public dials of the Museum. The Shortt clock was perfected by Mr. W. H. Shortt in 1921 as a result of a long period of experimental work in association with Mr. F. Hope-Jones and the Synchronome Company; the first elock was set up at the Edinburgh Royal Observatory in 1921, and Prof. R. A. Sampson's report on its first year's run aroused great interest among astronomers, as it had proved to have surpassed all previous clocks in its accuracy. A Shortt clock was adopted as the sidereal standard at Greenwich at the beginning of 1925, and has proved itself capable of measuring time to an accuracy of a few thousandths of a second per day, or better than 1 in $10^{7}$. The clock now exhibited in the Science Museum is identical with these observatory clocks except that the usual exhausted copper case for the free pendulum is replaced by a dust-tight glass cylinder : the clock is mounted on the wall of a public gallery with its slave elock by its side. The delicate method of imparting an impulse to the free pendulum and the action of the hit-and-miss synchroniser can thus be studied in detail.

\section{Excavations at Jericho, 1934-35}

Durrvg the season which has just closed, Sir Charles Marston's archæological expedition to Jericho, of which Prof. John Garstang is field director, has penetrated to the neolithic levels of earliest occupation which, it is found, cover a considerable portion of the site, under deposits of the Early Bronze Age measuring $27 \mathrm{ft}$. thick. In the neolithic levels, forming a layer $18 \mathrm{ft}$. deep, were found sealed deposits in the form of a series of superimposed house structures, in which the floors had been plastered, coloured red, and burnished. There is evidence to show that the walls of these structures had been treated in a similar fashion. One of the most interesting finds, according to a dispatch reporting the results of the excavation in The Times of April 4, is the head of a cult image of human form made of unbaked clay, in which the eyes are represented by shells. It was found in association with sherds of Thessalian painted pottery and fragments of primitive local ware imme. diately below the Early Bronze Age levels. The flint 